\title{
過去20年間における日本放射線技術学会総会の 研究発表からみた放射線技術の推移
}

\author{
北海道支部 \\ 金子順 次 -中島安三・中間 光 雄 \\ （論文受付 40 年 5 月 4 日）
}

\section{1. まえがき}

日本放射線技術学会は昭和17年11月16日現名誉会員滝 内政治郎先生が中心之なり各地㳻散在するエックス線技 術者の10余団体を統合するため京都において創立準備委 員会を開催し，その後統一運動は順調に進捗し，图和18 年 3 月 28,29 日の雨日福岡市九州大学において第 1 回設 立総会を日本レントゲン技術員学会として開催して開催 した．その後第 2 回総会で日本放射線技術学会と改称し て雨来，終戦後の苦難を乗り越元毎年開催する年度総会 は，年を経るととすに隆昌発展し，昭和39年第20回を終 えるに当たり，たまたま技術史編纂の機運が盛んとなっ てきた。
またわれわれの北海道支部は地域的に津軽の海で本州 と境し, いろいろの意味汃ら特殊事情を有し, 学会支部 としての発展過程沈いても異なったとてろが見受けら れ，独自の立場においてその経過を記述しておく必要む 感じ，その目的加らまず学会総会における北海道の位置 を知るために発表抄録によって $2 ， 3$ の統計的考察を試 みるしとにしたが，総会抄録，10周年記合号などの内容 によって得た資料からは，いささか疑問の点ああるが， われわれが整理した事柄についてととに報告し，先輩諸 氏のご批判とで指導を願う次第である。

\section{2. 年度総会期日, 開催地, 会長など について}

表 1 日本放射線技術学会年度総会 期日，開催地，会長

\begin{tabular}{|c|c|c|c|c|c|c|c|c|c|c|c|c|c|}
\hline 年度 & 回 & 期 & 開催地 & 演題数 & 名 & 誉 & 会 & 長 & \multicolumn{3}{|c|}{ 会 } & 会 & 長 \\
\hline 1 & 1 & $18-3-28, \quad 29$ & 福 岡 & 18 & 中 & 島 & 良 & 貞. & \multirow{2}{*}{\multicolumn{3}{|c|}{ 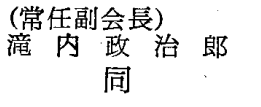 }} & 高＼cjkstart宮＼cjkstart康 & 治 \\
\hline 5 & 2 & $21-6-9$ & 京 都 & 6 & 中 & 泉 & 正 & 徳 & & & & 梅 谷 友 & 吉 \\
\hline 6 & 3 & $22-4-4$ & 大 阪 & 18 & 長 & 橋 & 正 & 道 & \multicolumn{3}{|c|}{ 同 } & 仲 川 庄 & 次 \\
\hline 7 & 4 & $23-4-4,5$ & 東 京 & 27 & 樋 & 口 & 助 & 弘 & \multicolumn{3}{|c|}{$\begin{array}{l}\text { (会長) 滝内政治郎 } \\
\text { (副会長)梅 商吉 }\end{array}$} & 関 忠 & 孝 \\
\hline 8 & 5 & $24-5-1,2$ & 们 台 & 21 & 古 & 賀 & 良 & 彦 & \multicolumn{3}{|c|}{ 滝 内政 治 郎 } & 石田熊次 & 郎 \\
\hline 9 & 6 & $25-4-16, \quad 17$ & 金 沢 & 51 & 平 & 松. & & 博 & \multicolumn{3}{|c|}{ 同 } & 三 上 徹 & 吉 \\
\hline 10 & 7 & $26-4-4, \quad 5$ & 東 京 & 45 & 本 & 島 楖 & $1 之$ & 助 & \multicolumn{3}{|c|}{ 同 } & 綱 川 高 & 美 \\
\hline 11 & 8 & $27-4-5, \quad 6$ & 大 阪 & 60 & 西 & 岡 & 時 & 雄 & 細 & 江 謙 & $\equiv$ & 新 閃 次 & 郎 \\
\hline 12 & 9 & $28-4-6, \quad 7$ & 熊 本 & 85 & 亀 & 田 & 魆 & 輔 & \multicolumn{3}{|c|}{ 同 } & 江 島 明 & 酒 \\
\hline 13 & 10 & $29-4-3, \quad 4$ & 岡 山 & 75 & 武 & 田 & 俊 & 光 & \multicolumn{3}{|c|}{ 同 } & 脇 本 才 & 志 \\
\hline 14 & 11 & $30-4-4,5$ & 京 都 & 105 & 後 & 藤 & 五 & 郎 & \multicolumn{3}{|c|}{ 同 } & 福 岡 太 & 郎 \\
\hline 15 & 12 & $31-4-1,2,3$ & 東 京 & 104 & 春 & 名 & 英 & 之 & 関 & 忠 & 孝 & 荒 川 & 昌 \\
\hline 16 & 13 & $32-4-30,5-1,2$ & 新 潟 & 124 & 野 & 崎 & 秀 & 英 & \multicolumn{3}{|c|}{ 同 } & 泚谷慶一 & 郎 \\
\hline 17 & 14 & $33-3-31,4-1,2$ & 福 岡 & 132 & 入 & 江 & 英 & 雄 & 青 & 木重 & 秋 & & \\
\hline 18 & 15 & $34-4-3,4,5$ & 東 京 & 112 & 苯 & 本 & 憲 & 甫 & 田 & 中 金 & 司 & & \\
\hline 19 & 16 & $35-6-30,7-1,2$ & 札 幌 & 128 & 若 & 林 & & 勝 & 金 & 子 順 & 治 & & \\
\hline 20 & 17 & $36-4-2,3,4$ & 大 阪 & 146 & 藤 & 野 & 守 & 次 & 梅 & 谷 友 & 吉 & & \\
\hline 21 & 18 & $37-4-2,3,4$ & 名古屋 & 126 & 高 & 橋 & 信 & 次 & 細 & 江 謙 & $\equiv$ & & \\
\hline 22 & 19 & $38-4-3,4,5$ & 大 阪 & 124 & II & 入 & & 弘 & 林 & 周 & $=$ & & \\
\hline 23 & 20 & $39-5-17,18,19$ & 盛 岡 & 153 & 足 & 次 & 之 & 助 & 樋 & 口喜代。 & 治 & & \\
\hline
\end{tabular}


本会は昭和 17 年度に創立されたがその総会は昭和 18 年 3 月に開催され, その後昭和 19,20 年は戦渦のため中止 の止むなきにいたり，昭和21年よりは戦災復興の苦しみ の中にも毎年順調に開催され，昭和39年には第20回の終 了をみた。（表 1)

本学会総会の開催期日, 開催地, 名誉会長は日本医学 放射線学会総会によって定められるよううなもので期日 は同学会に前後し, 開催地は同じ, 名誉会長は年度医学 放射線学会長を推戴している。

会期は 2,3 回は演題数からみても，また終戦直後の 交通，宿泊，食糧事情などから総会は 1 日で終了してい る。その他の年度は 2 日間を要し，昭和 31 年第12回（東 京）より演題数は常に 100 題を越え，特別講演，宿題報 告, シンポジウムなど学会行事も多彩になり会期は 3 日 間に延長し，昭和38年第19回（大阪）上りは討論会など も行ない，発表形式む資料展示と口述に分け，限られた 会期を有意義に計画し参加者に理解し易いよう努力され てきた。

創立当時は会長を設けず常任，年度の両副会長制をと ったが，昭和23年第 3 回より会長および年度副会長制に 変更，さらに昭和33年第14回より年度会長制をとった。 歴代会長, 副会長は表に示す通りで, 開催地の会員は会 長を中心にそれぞれ本会の向上発展のため非常な苦労を されたととを感謝する次第である。

過去20回にわたる総会開催地を地図の上よりみると表 1 図のように関東, 関西, 中京地区で過半数を示めてい るととは日本の文化の中心は本学会の中心とも言える。

\section{3. 特別講演について}

特別講演者はすべて会員外でその道の権威ある人に依 頼し, 第 1 回総会より続けられているがその演題名, 所 属，氏名は表 2 亿示した。

\section{4. 宿題報告, シンポジゥム, 討論会 について}

会員の宿題報告についは表 3 にるように昭和 28 年第 9 回 (熊本) より続けられ, エックス線装置, 撮影法, 写真などに関するものが多く, 線量測定, 散乱線, 防護 関係が 2,3 挙げられている。

シンポジムは表 4 のように昭和 31 年第 12 回（東京） より開始され毎年続けられているが，宿題報告と似かよ った演題もある。しかし主旨が積年の研究業績に対する 栄誉を与えさらに進んだ追及を求めた報告と，ただ討論 をみちびきだすととを主体とした発表との違いと考える べきであろう.

討論会は炤和36年第19回（大阪）より始まったもので まだ日浅く今後どのように進展するかは不明であるが研 究発表のように科学に立脚した敩然とした数字, 理論な どの報告ではなく題名を中心に単なる話し合いの場と言 う目的であり, 気楽さと理解し剔い興味あるととで今後 の発展を期待したい。

\section{5. ブロック別 (県別) 発表演題数 について}

1) 年度別演題数について

\section{日本放射線技術学会 年度総会開催地}

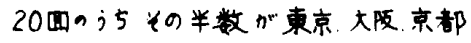
名古㾏の中心地において開催されている。

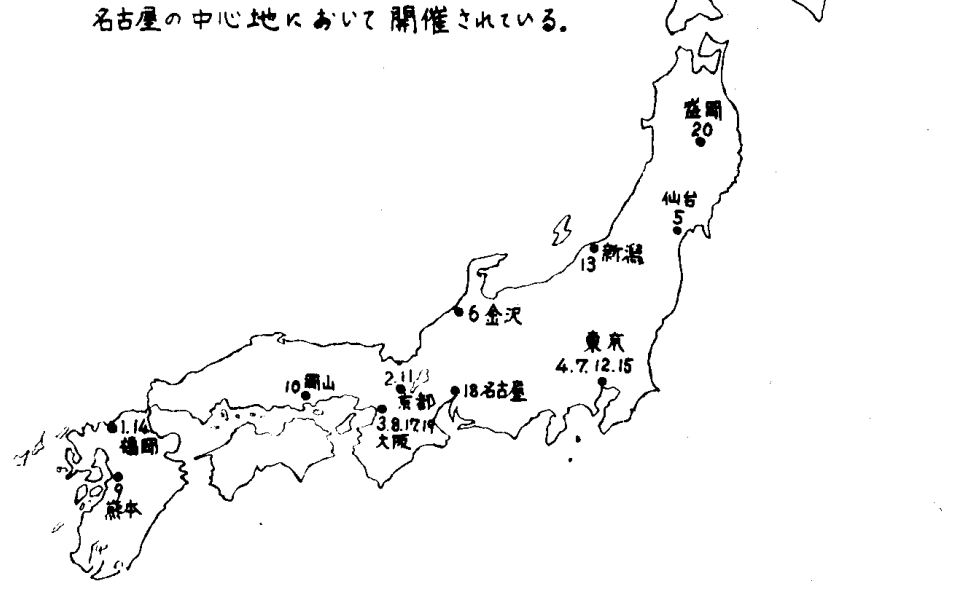

第 1 図

過去20回の総会発表, 演題総数は表 5 亿示す ように，1,660題の龙大な数を示し， 5 年ごとに 階段的な増加を示している，すなわち創立後 5 年間は年平均 18 題， 10 年までは 63 題，15年まで 115題，20年まで135題と増加していてる。この 急激な増加は社会事情と科学の急激な進歩によ るもので，昭和 25 年頃までは日本人は生きるこ とに苦労を重ねた時代であった. その後 30 年頃 までは除々にあらゆるものが復興して，科学え の心構えも旺盛になってきた．炤和 30 年を過ぎ れば急速に社会事情は好転し，生活む豊汃にな りそれぞれ他の職業む共により高度な科学的進 歩をむたらし放射線技術界汇む装置, 撮影法, 防護その他あらゆる方面に進歩改良が激しく加 えられ，また技師法制定によるエックス線技師 学校教育の確立によってて高度の知識, 技術が養 
表 2 日本放射線技術学会総会，特別講演

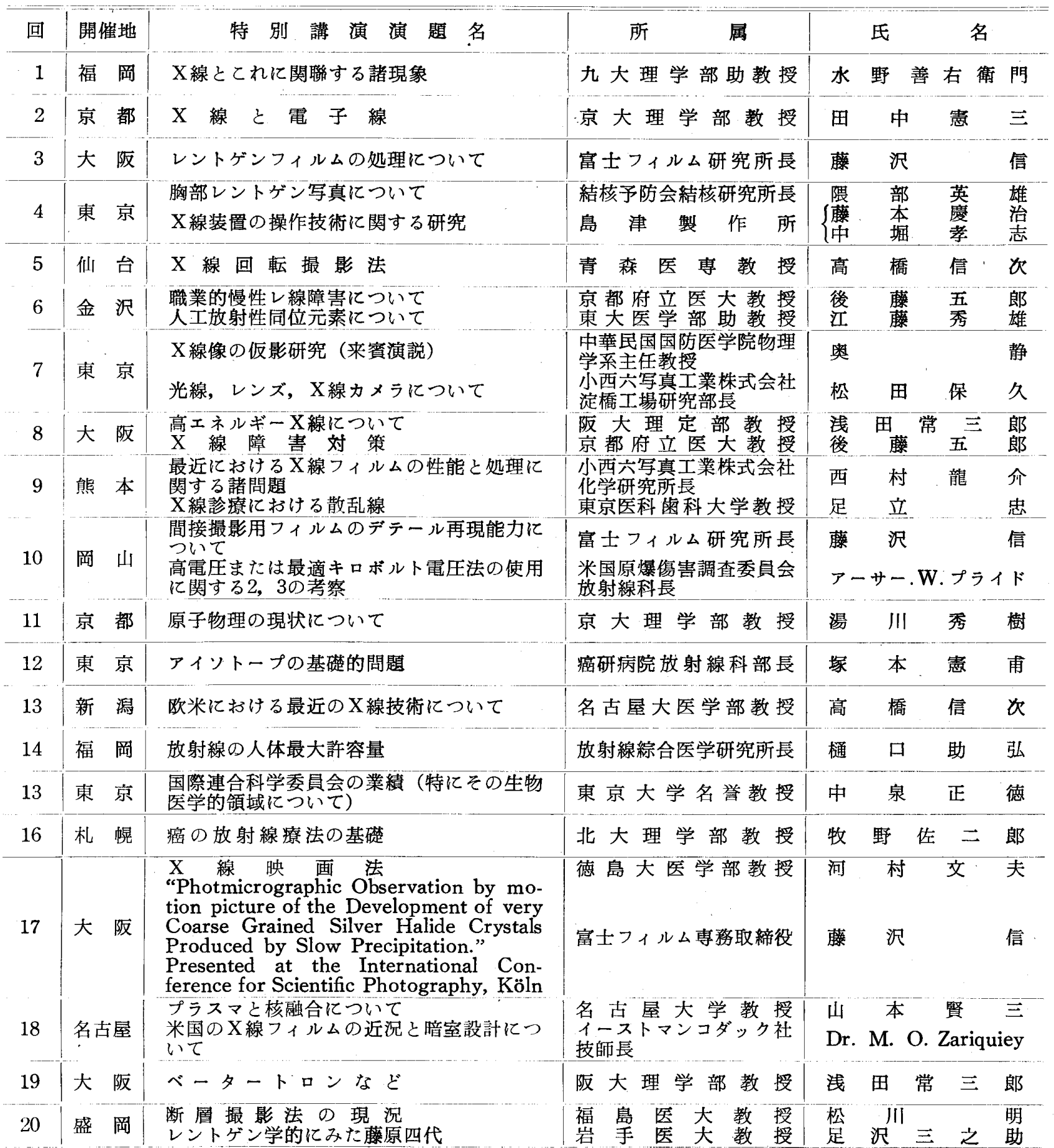

成され共々大きな発展に進んだ。

\section{2) ブロック別発表演題数について}

本学会は 7 ブロックに区分され活動を続けているが20 年間の演題数 1,660 題からみると関東, 関西でそれぞれ 30\%を越え，次いで中京地区の15\%となっている。過去 20年間の推移をみると前半は関西, 中国, 四国で演題数 の大半を示めていた。しれはその当時との地方に学会の 発展に力を入れた人々が多く, 毎年の発表者をみると多
くは限られた人々でなされていたようにあ思われる。ま た創立頭初は北海道，九州など遠隔地と中央との差はあ まり見受けられないととは，前述したように生きるとと に精魂を尽していた時代は田舎の方が住みよい環境にあ ったとあ言える. 安定してきた社会環境となった昭和30 年以後はその差が逆にはなはだしくひらいて東京を中心 に大きく伸びている．乙れはエックス線関係の大メ一カ 一が東京周迅に多く, 大学あるいは大病院と提携して技 
表 3 日本放射線技術学会総会 宿題報告

\begin{tabular}{|c|c|c|}
\hline 回 & 開催地 & 宿 題 報 告 演 題 名 \\
\hline 9 & 熊 本 & 肺藏撮影に関する基本的諸問題の検討 \\
\hline 10 & 岡 山 & 増感紙の性能評価に関する研究 \\
\hline 11 & 京 都 & 䛦療時における散乱X線について \\
\hline 12 & 東 京 & 撮影条件に対するブレンデの影響に関する奏験的研究 \\
\hline 13 & 新 潟 & $\begin{array}{l}\text { 現像液の老化について（主としてレントゲン写真現像 } \\
\text { にる老化）. }\end{array}$ \\
\hline 14 & 福 岡 & 骨撮影の基礎問題 \\
\hline 15 & 東 京 & 間接撮影の基礎的研究 \\
\hline 16 & 札 幌 & $\begin{array}{l}\text { 高速度撮影法 } \\
\text { 蓄電器放電式装置の放電制御 }\end{array}$ \\
\hline 17 & 大 阪 & $\mathrm{X}$ 線写真像示現の限界 \\
\hline 18 & 名古屋 & X線写真撮影時における露出条件について \\
\hline 19 & 大 阪 & 線量測定の諸問題 \\
\hline 20 & 盛，岡 & X線写真の画質におよばす因子の研究 \\
\hline
\end{tabular}

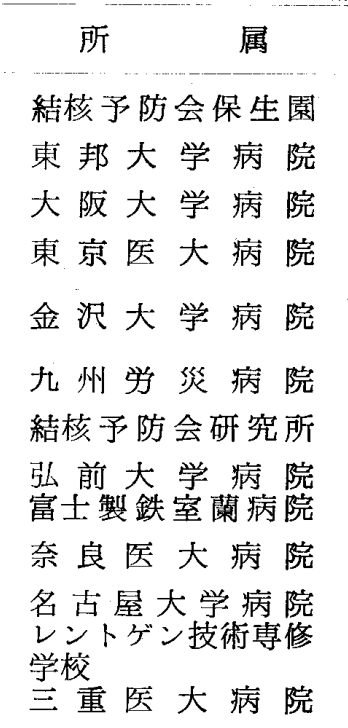

氏 名

\begin{tabular}{|c|c|c|}
\hline 綱 & 川 & 高 \\
\hline 飭 & 塚 & 芳 \\
\hline 二 & 宮 & \\
\hline 浩 & 理 & 正 \\
\hline 三 & 上 & 徹 \\
\hline 熊 & 谷 & 定 \\
\hline 川 & 㱦 & 幸 \\
\hline & 藤 & 五 \\
\hline & 谷 & 鉄 \\
\hline
\end{tabular}

奥 村彦太 郎 木 村 幾 生 中，村実

表 4 日本放射線技術学会総会 シンポジウム

\begin{tabular}{|c|c|c|c|c|}
\hline 回 & 開催地 & 題 名 & 座 & 演 \\
\hline 12 & 東 京 & 散 乱 線 防 護 & & 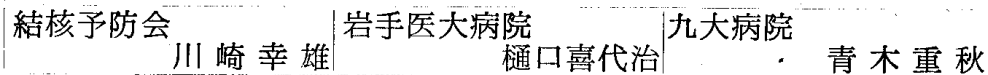 \\
\hline 13 & 新 鼬 & $\begin{array}{l}\text { 乳檪の胸部X線写 } \\
\text { 真について }\end{array}$ & & 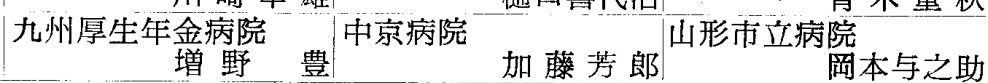 \\
\hline 14 & 福 岡 & 胸椎の撮影につい & & 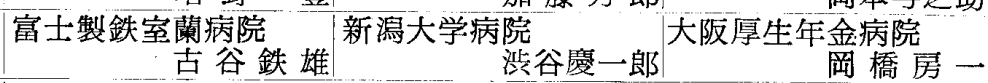 \\
\hline 15 & 東 京 & $\mathrm{X}$ 線 自 動 車 & $\begin{array}{l}\text { 東京日通病院 } \\
\text { 島 田豈 治 }\end{array} \mid$ & 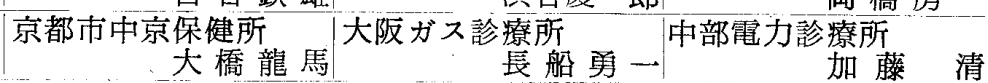 \\
\hline 16 & 札 幌 & $\begin{array}{l}\text { 診療時における被 } \\
\text { 曝線 }\end{array}$ & $\left|\begin{array}{c}\text { 岩手医大病院 } \\
\text { 樋口喜代治 }\end{array}\right|$ & \begin{tabular}{|}
$\mid$ 国立北海道第二療金所 \\
中国立公采衛生院 \\
光 雄
\end{tabular} \\
\hline 17 & 大 & $\begin{array}{l}\text { 撮影時における散 } \\
\text { 乱線フィルムにお } \\
\text { よぼす影響 }\end{array}$ & $\begin{array}{l}\text { 三重大学病院 } \\
\text { 中 }\end{array}$ & 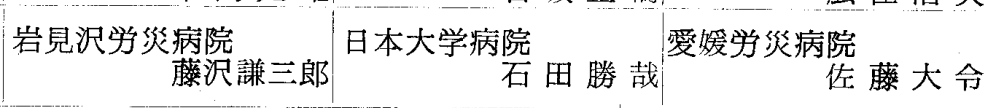 \\
\hline 18 & 名古屋 & X線写真暗室処理 & $\begin{array}{r}\text { 名古幄大学病院 } \\
\text { 細 江 謙 }\end{array}$ & 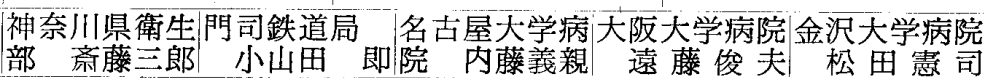 \\
\hline 19 & 大 阪 & $\begin{array}{l}\text { 胸骨並びに肋骨撮 } \\
\text { 影法 }\end{array}$ & $\begin{array}{l}\text { 奈良医大病院 } \\
\text { 林 周 }\end{array}$ & 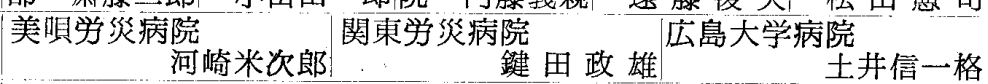 \\
\hline 20 & 盛 岡 & 化線撮影法の自動 & $\begin{array}{c}\text { 岩手医大病院 } \\
\text { 樋口喜代治 }\end{array}$ & 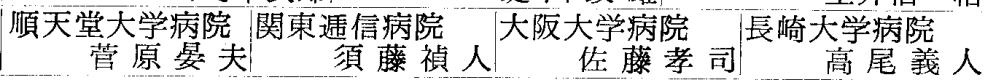 \\
\hline
\end{tabular}

日本放射線技術学会総会 討諭会

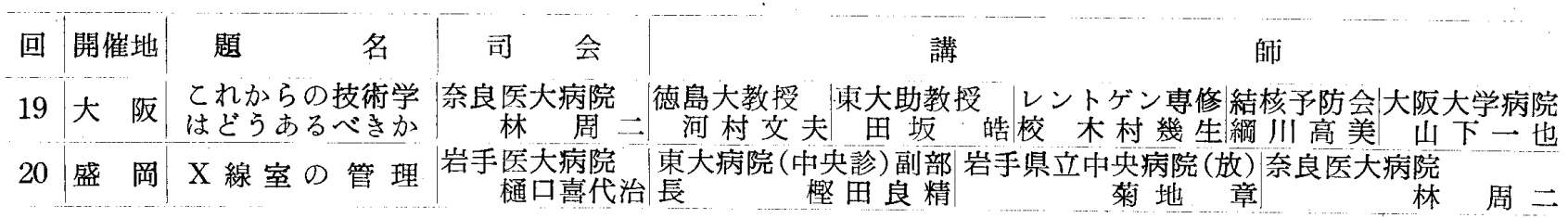

術の進歩をもたらし，また大企業の付属病院，公共団体 の大病院などで新鋭装置を備え付计医療の研究が容易と なってきたからであろう。

\section{3）20年間の各県別発表総数について}

各県別に発表数を分類してみると図 2 のように東京都 347 題を首位に, 大阪府 271 題, 京都府 180 題, 愛知県 111 題の順で55\%に抢よんでいる。 またてれらの中心地の周
辺を併わせると総演題数の75\%に達し，乙れらの中心地 を離れるにしたがって演題数は減少しているが, 演題数 の多塞によってその地方の技術水準を論ずるととは不適 であるし，発表演題の中には発表に伍するか疑問なむの もないではない.われわれの学会では医学会と異なり貴 重な研究業績があっても勤務の関係から総会に出席不能 の場合むあり，乙の点州心地を離机るほど不遇とも言え 
表 5 ブロック初発表演頻数の推移

\begin{tabular}{|c|c|c|c|c|c|c|c|c|c|c|c|c|}
\hline & & & & 東北・新潟 & 関東・甲信 & 東海・北陸 & 近 & 中国・四国 & 九 & & & \\
\hline 年度 & 回 & $\begin{array}{l}\text { 演 } \\
\text { 題 } \\
\text { 数 }\end{array}$ & 北海道 & $\begin{array}{l}\text { 青森, 秋田, } \\
\text { 岩手, 宮城, } \\
\text { 山形, 福島, } \\
\text { 新潟 }\end{array}$ & $\begin{array}{l}\text { 東京, 埼王, } \\
\text { 干葉, 神奈 } \\
\text { 川, 山梨, } \\
\text { 長野, 群馬, } \\
\text { 柨木, 茨城 }\end{array}$ & \begin{tabular}{|l|} 
\\
静岡, 愛知, \\
三重, 肢阜, \\
福茾, 富山, \\
石川
\end{tabular} & $\begin{array}{l}\text { 京都, 大阪, } \\
\text { 滋賀, 奈良, } \\
\text { 兵庫, 和歌 } \\
\text { 山 }\end{array}$ & 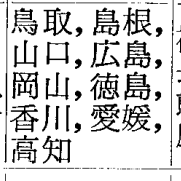 & 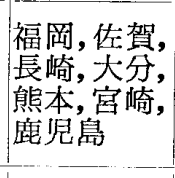 & その他 & 不 & 明 \\
\hline 18 & 1 & 18 & 1 & 1 & 2 & 4 & 5 & 1 & 2 & 2 & & \\
\hline 21 & 2 & 6 & & & 1 & 1 & 3 & 1 & & & & 2 \\
\hline 22 & 3 & 18 & 1 & & 1 & 3 & 7 & 4 & & & & \\
\hline 23 & 4 & 27 & 1 & & 3 & 3 & 11 & 6 & 3 & & & \\
\hline 24 & 5 & 21 & 2 & 6 & & 4 & 6 & 3 & & & & \\
\hline $18 \sim 24$ & $1 \sim 5$ & 90 & 5 & 7 & 7 & 15 & 32 & 15 & 5 & 2 & & 2 \\
\hline 25 & 6 & 51 & 5 & 3 & 10 & 4 & 15 & 11 & 1 & & & 2 \\
\hline 26 & 7 & 45 & 1 & 3 & 13 & 8 & 15 & 4 & 1 & & & \\
\hline 27 & 8 & 60 & 2 & 4 & 19 & 10 & 16 & 6 & 3 & & & \\
\hline 28 & 9 & 85 & & 5 & 20 & 10 & 36 & 7 & 7 & & . & \\
\hline 29 & 10 & 75 & & 3 & 22 & 9 & 28 & 10 & 3 & & & \\
\hline $25 \sim 29$ & $6 \sim 10$ & 316 & 8 & 18 & 84 & 41 & 110 & 38 & 15 & & & 2 \\
\hline 30 & 11 & 105 & 1 & 7 & 21 & 20 & 41 & 11 & 4 & & & \\
\hline 31 & 12 & 104 & 1 & 6 & 23 & 18 & 40 & 10 & 6 & & & \\
\hline 32 & 13 & 124 & 1 & 7 & 39 & 17 & 45 & 10 & 5 & & & \\
\hline 33 & 14 & 132 & 1 & 5 & 39 & 20 & 38 & 15 & 13 & & & 1 \\
\hline 34 & 15 & 112 & 2 & 6 & 20 & 21 & 42 & 14 & 7 & & & \\
\hline $30 \sim 34 \mid 1$ & $11 \sim 15$ & 577 & 6 & 31 & 142 & 96 & 206 & 60 & 35 & & & 1 \\
\hline 35 & 16 & 128 & 3 & 6 & 50 & 22 & 28 & 7 & 10 & . & & 2 \\
\hline 36 & 17 & 146 & 2 & 11 & 55 & 27 & 35 & 7 & 7 & & & 2 \\
\hline 37 & 18 & 126 & 4 & 7 & 50 & 12 & 38 & 7 & 7 & & & 1 \\
\hline 38 & 19 & 124 & 4 & 10 & 52 & 17 & 24 & 11 & 5 & 1 & & \\
\hline 39 & 20 & 153 & 3 & 15 & 72 & 19 & 29 & 8 & 6 & & & 1 \\
\hline $35 \sim 39 \mid 1$ & $16 \sim 20$ & 677 & 16 & 49 & 279 & 97 & 154 & 40 & 35 & 1 & & 6 \\
\hline & $1 \sim 20$ & $\begin{array}{l}1,660 \\
(100)\end{array}$ & $\begin{array}{c}35 \\
(2.11)\end{array}$ & $\begin{array}{r}105 \\
(6.33)\end{array}$ & $\begin{array}{r}512 \\
(30.84) \\
\end{array}$ & $\begin{array}{r}249 \\
(15.00)\end{array}$ & $\begin{array}{r}502 \\
(30.24) \\
\end{array}$ & $\begin{array}{r}153 \\
(9.22)\end{array}$ & $\begin{array}{r}90 \\
(5.42) \\
\end{array}$ & $\left(\begin{array}{c}3 \\
(0.18)\end{array}\right.$ & $\begin{array}{r}1 \\
(0.66\end{array}$ & \\
\hline
\end{tabular}

（注）この調査に当って本社が東京で工場が他県の場合工場所在地が記されてれ机ばその県に，さもなければ本社所 在地とした。所属県の不明のものは1959年放射線銘鑑によって調査した。

る.

表 5 のブロックに含まないその他の地域は第 1 回は 満洲, 第19回はアメリカからのむのである. 所属県が不 明の演題むあり，はなはだしいのは抄録に氏名のみの記 載むある.今後発表の責任をむつためにも発表者の所属 は明らかにしておく必要ああろう。

\section{6. 職域別からみた演題数}

職域別にみると表 6 のように大学(各種研究所を含む) 関係は総数で 552 題 $33.25 \%$ ，各メーカー関係は 264 題 15.
90\%で合わせて約50\%を示していることは，20年閪の各 年度平均したとしろでX線技術は雨者によって大きく進 步発展がなされたとと在意味する。次いで都道府県立の, 123題7.41\%, 国立の 119 題7.19\%の順であるが今後市立 学災, 聥信, 日赤, 鉄道, 厭生年金その他の基幹病院に 大規模な装置を備え付りる傾向にあり将来に期待する之 ころが大きい，また鉄道を始好多災，派信，日赤などで は独自の発表会を持って団体自体としては大きな発展を を示しているが，つとめて本会の発表機関にす協力を的 がいたいととろである。 


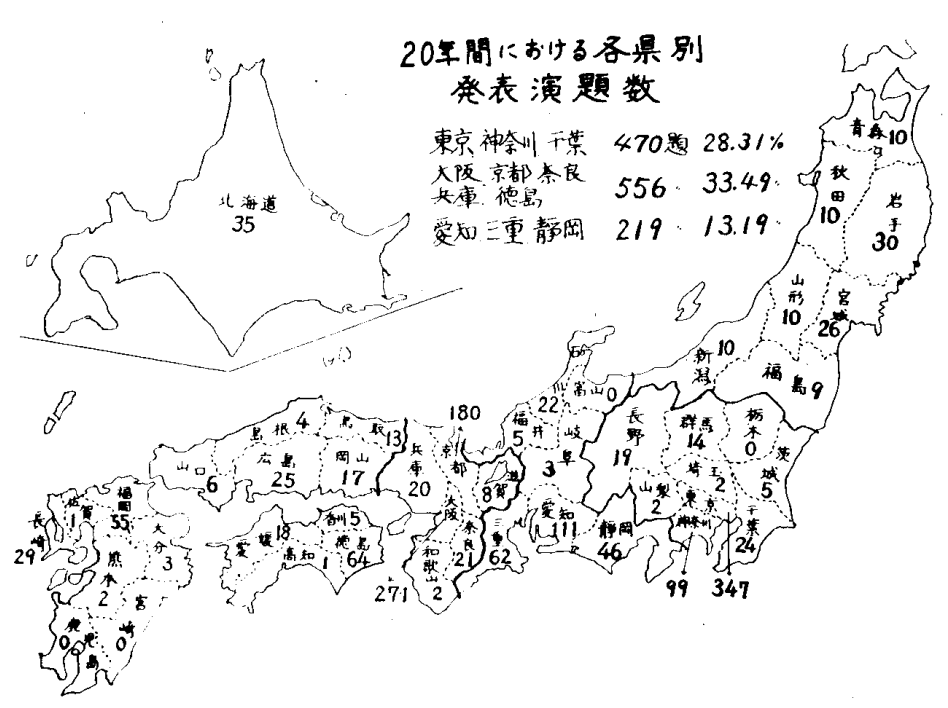

第 2 図

また，町村立，個人病院などは非常に発表数は少ない が，新しいことのみが進歩ではないし，独自の工夫もあ るととであろう・グループによる共同発表などによって 常に前向きの姿勢であることを希望したい。

\section{7. 研究発表の内容からみた演題の推移}

総会発表の内容を検㔀して表 7 のうに32に区分して みたが発表内容は複雑なものがあり簡学汇区分のできな

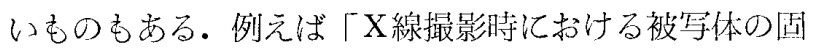
定执上び被曝線量の軽減上写点的効果について」と題し た場合 3 つ内容を有し集膟する人の主観が入らざるを 得ない。これらの実情から正確な集計を望めなかったが 以下発表内容の進步発层の大要を説明する.

\section{1） X線装置関係について}

20 年間に打汁万発表総数は，372朝で全体の $22.41 \%$ 示め本学会㓣立より前半の10年間には大きな進歩はなか ったが炤和30年頃より急激に進歩し，配電盤上の操作は 拥ボタン式の自動化に進み, 計器, タイマーの正確度が 強く要球され精度の高い, 使い易い装置仙政良されつつ ある. 整流管には半導体が使われてセレン, シリコン整 流器などの報告もみられ，X線管は固定陽極よりほとん ぞが回転陽極管汇変わり, 焦点外X線の除去とX線防護 の観点加らしゃ蔽X線管の報告むるる, ツーブスは多重 シャッターが盛んに用いられるようになったし，また微 小焦点の出現によって拡大撮影老可能にした。一庁透視 䛦断の進少む激しく，操作のし易く，より辉度の高い明 るい透視え己進み透視台でX線の遠隔制御, 患者の体什 変換をできるだ忖電動的に行ない, 透視よりの狙撃撮影 を可能已し，乙れらは峉らゆる透視台に付属し一般化し てしまった。ささらに蛍光増倍管によって明るい室での透
視から進んでX線テレビの出現となってX線像 の再現はビデオテープにより行なわれその技術 む高度に進んでいる。

戦後電源事情により発達した蓄電器放電式 $\mathrm{X}$ 線装置は電力の開発と進歩により大形装置から は自然に姿を消し，間接撮影装置に大きく取り 入れられ総てが蓄電器式となり 3 極 $\mathrm{X}$ 線管の出 現, 波尾截断, ホトタイマー, フィルム巻取と 組合わされて全自動化し，可般型化適するよう にこれらが軽量小型化化努力されている. 澏対 策により近年は間接撮影も高電圧装置に進み, カメラはレンズカメラよりミラーカメラが採用 されるようになりその写真は鮮鋭にして診断洒 値の高いむのになるととむに被曝量の娍少をは かった。

集団検竞の曾及発展によりX線自動車が街や村を走る ようになって，乙の改良工夫えの献告むされている。

従来，X線彰断はコントラストを強く要求されていた が, X線詮断に必要な写真は適当な, 黒化度があり鮮鋭 にして十分に描写された識別能を有するものと言うX線 診断の進歩と被検者の被曝量の減少加ら，乙れ適した 高電生装置の製作も盛んになった。また胸部外科の進歩 により断居写真が重要視され，乙の装置の改良工夫む目 ざましく一方向運動のみならず，附道運動，回転横断 など多くの方法が若案されている。

\section{2) X線付属品について}

付属品の研究は, 撮影時の散乱線除去具 (ブレンデ) が最す多く，い汃してて散乱線除去を行ない優秀なX線 写真老得るか汇努扎ているかが知られる。次いでフィ ルム取枠, 撮影台化関するものが多く見受故られ, 写真 技術に最む必要な順になるととは当然上言えよう。

\section{3）暗室作業について}

見在操作はバット・タンク見像が行なわれていたが, X線写真の処理枚数が增大してくる拈よび自動現像装 置汃普及し, また使用する現像淮は $M Q$ 現像薬の単菂 調合加ら PQ 現像薬の混合楽に変り, 定着液は単なる酸 性硬膜液より迅速定着混会剂となりこれらの研究も盛ん になってきた。

\section{4）蛍光体, 感光材料について}

増感紙は終戦值後の頃は一般用の 1 程糞であったが, その後低, 中, 高感度増感紙に分類され, さらに特殊部 断用フレキシブル, 補償增感紙など多くの研究が積まれ これが一般化した. 䖺光板は間接猳影用, 透視䜌断用に 区分され，年とともに残沈の少ない輝度の高い方向に進 


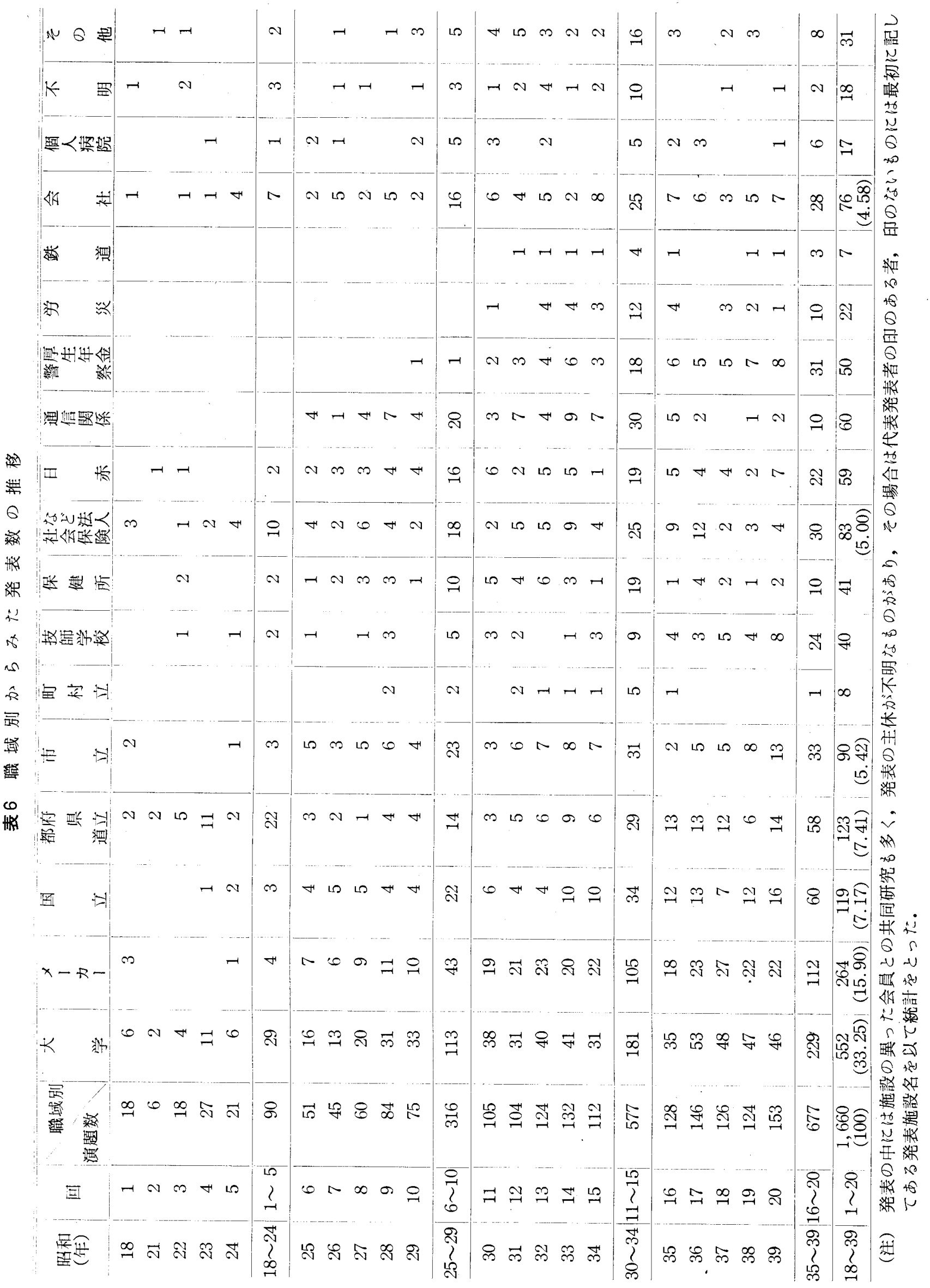


表 7 研究発表の内容

\begin{tabular}{|c|c|c|c|c|c|c|c|c|c|c|c|c|c|c|c|c|}
\hline \multirow{2}{*}{$\begin{array}{l}\text { 年 } \\
\text { 度 }\end{array}$} & \multirow[b]{2}{*}{ 回 } & \multirow{2}{*}{$\begin{array}{ll} & \text { 発 } \\
\text { 表 } \\
\text { 演 } \\
\text { 題 } \\
\text { 容 } \\
\text { 数 }\end{array}$} & \multirow{2}{*}{$\begin{array}{l}\text { 史 } \\
\text { 術 }\end{array}$} & \multirow{2}{*}{$\begin{array}{l}\mathrm{X} \\
\text { 線 } \\
\text { 設 } \\
\text { 䄍 } \\
\text { 䈏 }\end{array}$} & \multicolumn{2}{|c|}{$\mathrm{X}$ 線 } & \multicolumn{2}{|c|}{ 装 置 } & \multirow{2}{*}{$\begin{array}{l}\mathrm{X} \\
\text { 線 } \\
\text { 自 } \\
\text { 動 } \\
\text { 車 }\end{array}$} & \multirow{2}{*}{ 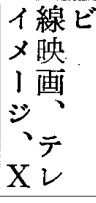 } & \multicolumn{2}{|c|}{ 附 属 品 } & \multirow{2}{*}{$\begin{array}{l}\text { 現水 } \\
\text { 家 } \\
\text { 着 } \\
\text { 洗 }\end{array}$} & \multirow{2}{*}{ 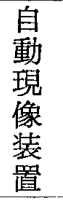 } & \multirow{2}{*}{ 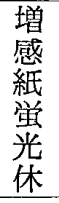 } & \multirow{2}{*}{$\begin{array}{l}\text { ᄀ感 } \\
\text { 亿光 } \\
\text { 材 } \\
\text { 材 } \\
\text { 料 }\end{array}$} \\
\hline & & & & & $\begin{array}{l}\text { 治診 } \\
\text { 療断 } \\
\text { 用 }\end{array}$ & $\begin{array}{l}\text { 蓄装 } \\
\text { 放 } \\
\text { 間 } \\
\text { 接置 }\end{array}$ & $\begin{array}{l}\text { 断 } \\
\text { 層 } \\
\text { 装 } \\
\text { 置 }\end{array}$ & $\begin{array}{l}\text { X整 } \\
\text { 線流 } \\
\text { 管管 }\end{array}$ & & & 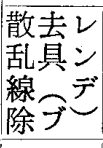 & $\begin{array}{l}\text { そ附 } \\
の \text { 属 } \\
\text { 他品 }\end{array}$ & & & & \\
\hline 18 & 1 & 18 & & & 4 & & & 1 & & 1 & & 1 & 2 & & & 1 \\
\hline 21 & 2 & 6 & 1 & & 1 & & & & & & & & & & & \\
\hline 22 & 3 & 18 & 1 & 1 & 2 & 1 & & & & & & & 2 & & 1 & 2 \\
\hline 23 & 4 & 27 & & 1 & 2 & & & 1 & & & 1 & & 3 & & 1 & 2 \\
\hline 24 & 5 & 21 & & & 3 & 2 & 1 & 1 & & & & & & & 3 & \\
\hline \multicolumn{2}{|c|}{${ }_{24}^{18} 1 \sim 5$} & 90 & 2 & 2 & 12 & 3 & 1 & 3 & & 1 & 1 & 1 & 7 & & 5 & 5 \\
\hline 25 & 6 & 51 & 2 & & 5 & 4 & 3 & 2 & & & 1 & 4 & 2 & & 3 & 1 \\
\hline 26 & 7 & 45 & & & 1 & 5 & 2 & & & & 1 & 1 & 3 & & 7 & 1 \\
\hline 27 & 8 & 60 & 1 & 1 & 4 & 9 & 4 & 1 & & & & 2 & 2 & & 4 & 4 \\
\hline 28 & 9 & 85 & & & 4 & 7 & 7 & & & & 3 & 6 & 1 & & 7 & 1 \\
\hline 29 & 10 & 75 & & & 9 & 1 & 1 & 4 & & & 1 & 4 & 4 & & 6 & 1 \\
\hline \multicolumn{2}{|c|}{$\begin{array}{l}25 \sim \\
29\end{array} \mid 10$} & 316 & 3 & 1 & 23 & 26 & 17 & 7 & 1 & & 6 & 17 & 12 & & 27 & 8 \\
\hline 30 & 11 & 105 & & & 5 & 9 & & 7 & & & 7 & 7 & 4 & & 10 & \\
\hline 31 & 12 & 104 & & 2 & 9 & 8 & 2 & 3 & 1 & & 5 & 3 & 2 & & 12 & 2 \\
\hline 32 & 13 & 124 & & 1 & 7 & 6 & 4 & 4 & & 4 & 5 & 6 & 5 & 1 & 4 & 3 \\
\hline 33 & 14 & 132 & & & 8 & 6 & 2 & 5 & 2 & 4 & 5 & 1 & 5 & & 6 & 3 \\
\hline 34 & 15 & 112 & & 2 & 8 & 7 & 1 & 5 & 2 & 3 & 4 & 3 & 5 & & 3 & 2 \\
\hline \multicolumn{2}{|c|}{$\begin{array}{c}30 \sim 11 \sim \\
\quad 34 \\
\end{array}$} & 577 & & 5 & 37 & 36 & 9 & 24 & 5 & 11 & 26 & 20 & 21 & 1 & 35 & 10 \\
\hline 35 & 16 & 128 & & 3 & 6 & 8 & 3 & 10 & 1 & 4 & 2 & 1 & 8 & 2 & 4 & 6 \\
\hline 36 & 17 & 146 & & 1 & 12 & 8 & 5 & 6 & 2 & 4 & 4 & 5 & 4 & 2 & 10 & 7 \\
\hline 37 & 18 & 126 & & 2 & 15 & 7 & & 4 & 1 & 7 & 2 & 4 & 4 & 3 & 8 & 2 \\
\hline 38 & 19 & 124 & & & 7 & 7 & & 2 & 1 & 9 & & 8 & 4 & & 4 & 6 \\
\hline 39 & 20 & 153 & & 2 & 12 & 6 & 1 & 3 & 1 & 4 & & 3 & 9 & 4 & 4 & 5 \\
\hline \multicolumn{2}{|c|}{\begin{tabular}{c|c|}
$35 \sim$ & $16 \sim$ \\
39 & 20 \\
\end{tabular}} & 677 & & 8 & 52 & 36 & 9 & 25 & 6 & 28 & 8 & 21 & 29 & 11 & 30 & 26 \\
\hline \multirow{2}{*}{$\begin{array}{c}18 \\
? \\
39\end{array}$} & \multirow{2}{*}{$\begin{array}{c}1 \\
2 \\
20\end{array}$} & \multirow{2}{*}{1,660} & 5 & 16 & 124 & 101 & 36 & 59 & 12 & 40 & 41 & 59 & 69 & 12 & 97 & 49 \\
\hline & & & & & \multicolumn{6}{|c|}{$372(22.41)$} & \multicolumn{2}{|c|}{$100(6.02)$} & \multicolumn{2}{|c|}{$81(4.88)$} & \multicolumn{2}{|c|}{$146(8.80)$} \\
\hline
\end{tabular}

んでいる.

X線フィルムはセーフライトに安全で, しかも高感度 で膜質も硬く粒状性に富えだ方向に進み，フィルムサイ ズについては旧態依然としたすのを用いているが，日本 人に適したものについての報告はしばしばなされている が実現にいたっていない, 間接用は $35 \mathrm{~mm}$ 穴ありより穴 なしに標準型がかわり，ミラーカメラによって $6 \times 6 \mathrm{~cm}$ 上り $7 \times 7 \mathrm{~cm}$ に大判となってきた.

\section{5） X線撮影法について}

本会創立頭初の報告は䏩部を始好骨骼一般撮影技術に 関するすのが多かったととは物資不足の国状から X線の
研究は出来なかったと言うととであろう．その後X線診 断とX線装置の高速な進歩と相まって新しい撮影法の研 究に拍車をかけ，その要求を満足させる成果を挙げてき た. 医師，メーカー，技師の 3 者が共同してX線殓憭の 向上発展に尽していることは毎年の発表を通じ明かに知 られるところで 20 年間における発表総数は631題で 38.01 \%を示めX線装置関係の $22.41 \%$ 合わして約 $60 \%$ にお よぶことはいかに而者が互いに進歩してきたかが知られ る.

撮影法の理論的考察も数式を用い理づめで解明するす の実際に撮影して写真上において説明するものの 2 つが 
からみた演題 数の推移

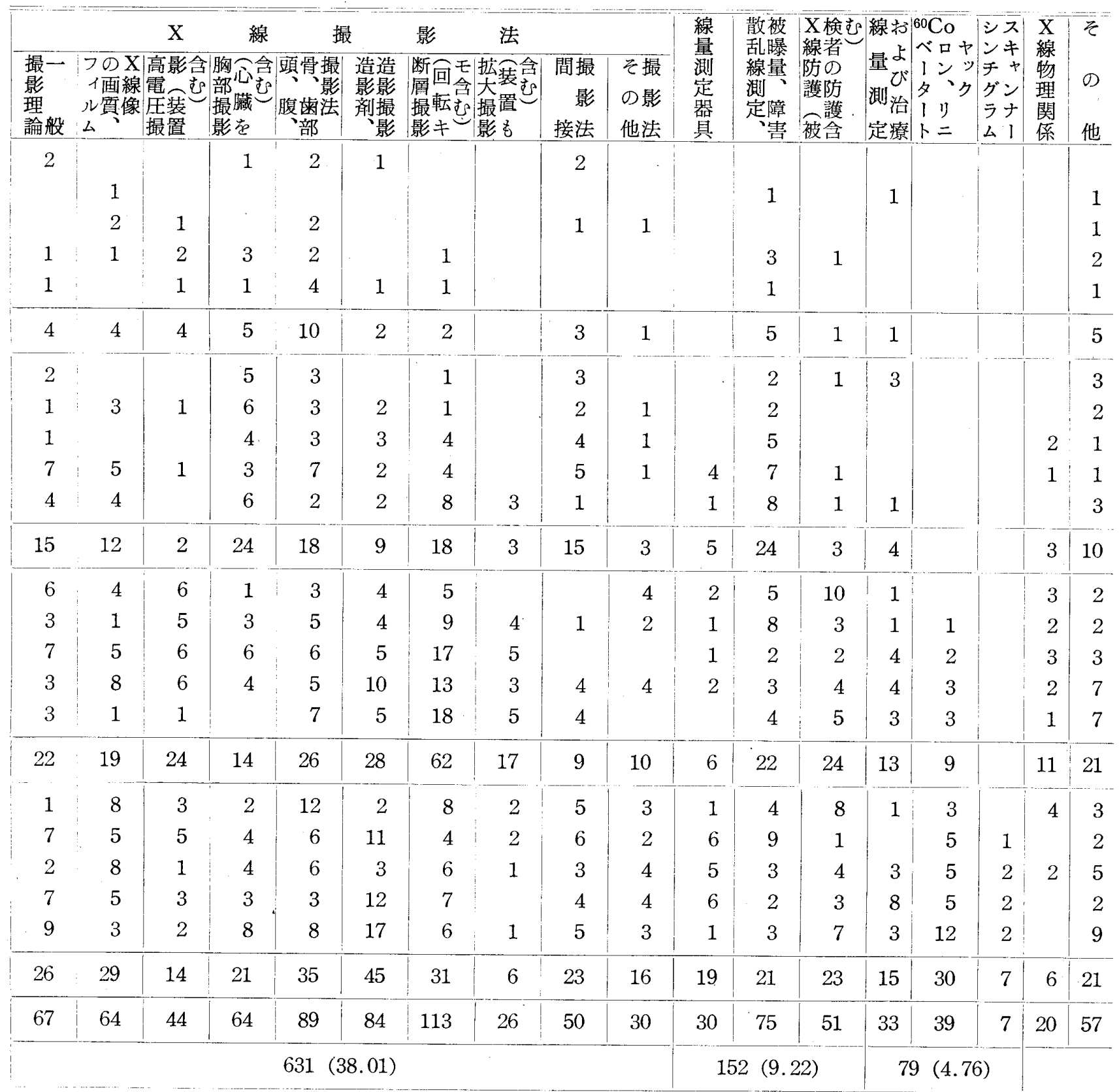

あり，次ぎにフィルムの画質，X線像てついては増感紙， 散乱線などの画質におよぼす影響, フィルム濃度, 解像 力，アレなどについてが多く見られる．高電圧撮影は装 置と組合わされて線質, 線量, 黒化度, 散乱線除去, 病 巣現出能などが検討されている.胸部, 一般骨骼撮影法 については多方向よりそれぞれの診断目的に合致した撮 影法を論じているすのが多いが，本会創立頭初より報告 が他の部よりみてはなはだしい堌加のないのは当時より 既に一般化した撮影術式の域を脱するとよがないからで ああろう。

造影剤およびその撮影法には近年高速度撮影装置の出
現によって肺, 心蔵血管造影が盛んに行なわれ, また脳 血管, 気管支, 胆垁造影法などが多いがこれに反し消化 管造影法は日常最も多く行なわれるととであるがこの報 告は少ない，乙れは造影撮影法としての技術的事項は従 来通りのことを踏襲しているためであろう。

断層撮影法は胸部のみに止まらず骨, その他の部位に むかなりの報告がみられ, また同時多層断層の茬案によ りそれに使用される増感紙, 撮影法などが一時かなりの 発表数を示した。抬大撮影法については 2 極X線管にバ イアス方式によって焦点を極微小にする方法が考えられ さらに $0.3 \mathrm{~mm}$ 焦点管の出現によって拡大撮影法は完成 
されたと言えるとの撮影法は焦点が微小であるととが 第一条件で当然この装置の研究と相まって撮影法の報告 が多くなされている。

間接撮影法は肺結核検診によって進歩し, 報告屯胸部 に限られた分野で岗り本学会創立以前汇多くの業績発表 があったようで，その後あまり多くはないが，近年胃癌 の早期発見のため間接撮影法が盛んに報告されてきた。 その他の撮影法に近接撮影法や乳房その他軟部撮影法 キセロラジオグラフィーなどの報告がある.

6) X線障害, 防護, 測定機器について

戦後放射線障害と乞の防護がやがしく論じられ撮影, 治療時の散乱線の分布状態や勤務者の被嚗線量, 障害, (血液)の程度，防護材料上防護方法，防護の実施による 被曝の減少などが多く報告され，近年遺伝的影響を考え ての被検者の性腺防護, 撮影時の被嚗量をい汃にして減 少さすべきかなどの報告が挙げられ，またとれらの測定 器の性能, 比較あるいは測定理論などの報告む多くなっ てきた。

7） X線量測定および治療, 高エネルギーについて

これらは医師の分野に入るためか20年間の前半には多 くの発表はなく, 最近X線量の測定理論や治療技術, コ バルト 60, ベータートロン, リニャックなどの高エネル ギー装置あるいはシンチグラム，スキャンナーなど放射 能測定機器と取組み放射線技師として既汇前向きの姿势 で研究に取り組んできたととは将来に大きく期待してよ い.

以上に要約してみたが新しい理諭と創造工夫によって 生まれたととがらに対しあらゆる分野より多くの放射線
技術者によって究明し，それを整理して一般化し普及さ せていくことが毎年の総会によく現われ，それが止まる ことなく前進している．乙れが学会が社会に貢献する由 縁とするとしろであろうが最近の10年間における進歩は まととに驚暎にあたいするすのがある。

\section{8. あ と がき}

過去20年間の本学会総会の業績からみた北海道支部の 位置について知る目的は達せられたが, 龙大にしてかつ 多岐にわたる発表内容の整理を正確にするととはわれわ れの到底でき得るものではなかった。特に職域別，発表 内容別についてみた場合それを細分する程集計する人の 主観が入り自ら墓穴を堀る類をま奴れなかった。しか し本学会総会の大きい進歩発展の過程について 1 つの角 度からみたものとして諸賢ので批判をいただけれげ幸い である。

「温古知新」の言葉のごとくわれわれは大勢の先輩各位. の業績の上に今後ますます本学会の発展に努力すること を願って止文ません。

終わりにで校閲とで指導を睗わりました本学会名誉会 員滝内政治郎，細江謙三，関忠孝先生，事務局長仲川庄 次先生に心から厚くお礼申し上げます。

参考 交 献

1）日本放射線技術学会総会演題集抢よび抄録（各年 度)

2) 日本放射線技術学会雑誌創刊10周年記念号（略和 30年)

3）日本医学放射線銘鑑（昭和34年医科器械够報社） 